\title{
Moura, Gerson. Relações Exteriores do Brasil (1939-1950): mudanças na natureza das relações Brasil-Estados Unidos durante e após a Segunda Guerra Mundial. 1a ed. Fundação Alexandre de Gusmão: Brasília, 2012, 277 p.
}

\author{
Marcella Winter $^{49}$
}

Gerson Moura é uma das principais referências quando se trata de Política Externa Brasileira e, mormente, no que tangea um dos mais tradicionais relacionamentos bilaterais do Brasil: os Estados Unidos. As expressões cunhadas por Moura em suas obras, a exemplo de "autonomia pela dependência" ou "alinhamento negociado", fazem parte do arcabouço conceitual da disciplina, como se a ela fossem intrínsecos. Por traduzir de forma tão enriquecedora as relações exteriores brasileiras, esclarecendo ao estudante e ao pesquisador diferentes estratégias de política externa adotadas ao longo de variados governos, Moura seja tão reconhecido e aclamado. Nos vinte anos de seu precoce falecimento, a Fundação Alexandre de Gusmão lança, em português, sua tese de doutorado, defendida, em 1982, no Reino Unido: "Relações Exteriores do Brasil (1939-1950): mudanças na natureza das relações Brasil-Estados Unidos durante e após a Segunda Guerra Mundial".

Por meio da obra, dividida em cinco capítulos, o autor contribui para a compreensão da política externa brasileira durante e após a Segunda Guerra, quando se aprofundou o alinhamento do país aos Estados Unidos. Moura busca, em sua análise, afastar-se de duas concepções recorrentes na literatura: a que enfatiza o oportunismo brasileiro na obtenção, junto aos norteamericanos, dos instrumentos necessários ao desenvolvimento nacional; e a ideia de que o Brasil estava submetido política e economicamente a Washington. Segundo o autor, a hegemonia norteamericana não impediu que o país delineasse suas estratégias de política externa autonomamente, ainda que houvesse constrangimentos e limites.

Moura traça um panorama para que se compreenda a influência dos Estados Unidos na formulação de linhas para a atuação internacional do Brasil desde o início da

49 Mestranda, bolsista Capes, do Programa de PósGraduação em Relações Internacionais da Universidade do Estado do Rio de Janeiro (PPGRI/UERJ)
República, e da América Latina. Após a Primeira Guerra, essa influência passaria a sofrer concorrência da Alemanha, principalmente no pensamento militar, o que teria suscitado novas políticas norte-americanas, a exemplo da Política da Boa Vizinhança e da tentativa de forjar uma unidade continental, por meio das Conferências Interamericanas. Nos anos 1930, Getúlio Vargas, por sua vez, optaria pelo equilíbrio pragmático entre os dois países, por intermédio do qual se obtiveram benefícios comerciais e teria sido aumentado o poder de barganha brasileiro frente aos dois parceiros. Como forma de aumentar sua influência sobre o país sul-americano e minar a atuação alemã, Washington buscaria aproximar-se do Rio de Janeiro por meio de promessas de cooperação econômica e militar.

A eclosão da Segunda Guerra causou efeitos significativos sobre a economia brasileira, que se apoiava na exportação. Nos anos iniciais do conflito, adotou-se a neutralidade, ao mesmo tempo em que se perseguiam dois objetivos principais: a industrialização e o reaparelhamento das Forças Armadas. Gerson Moura demonstra que, nesse momento, os Estados Unidos buscaram reafirmar sua hegemonia por meio de instrumentos culturais, na forma do OCIAA; militares, a exemplo do LendLease; e econômicos, por meio do Eximbank e de missões comerciais. O alinhamento aos EUA não somente se fortalecia, como se institucionalizava, com o estabelecimento de arranjos como o Tratado Interamericano de Assistência Recíproca; contudo, havia passivos na relação, como os referentes ao fornecimento de armamentos, acordado entre Washington e o Rio. Em 1942, o equilíbrio pragmático é descartado como estratégia de política externa: a Alemanha não mais tinha espaço nas formulações do Itamaraty e movimentos pró-Eixo eram reprimidos domesticamente. $\mathrm{O}$ afundamento dos navios brasileiros provocou a comoção necessária para que a declaração de guerra fosse apoiada como afirmação da soberania nacional. 
Moura destaca que desde que a proposta do envio de tropas foi lançada, os norte-americanos ofereciam resistências, principalmente devido à falta de preparo dos combatentes e da insistência excessiva do Rio de Janeiro, que atrelaria sua atuação ao envio de armas e outras formas de auxílio como meios para desempenhar papel relevante na guerra. O presidente Vargas instrumentalizou o interesse norte-americano de manter as bases militares no Nordeste e construir novas fortificações no Sul do país e, assim, possibilitou que o envio da Força Expedicionária Brasileira à Europa fosse aprovado. Embora o país tenha atuado timidamente, foi a ele possibilitada participação nos arranjos do pós-guerra. Ao final do conflito, segundo Moura, acreditava-se que a colaboração no teatro de guerra ocasionaria uma aliança especial com os Estados Unidos, o que ampliaria a projeção internacional do Brasil.

$\mathrm{O}$ autor demonstra que a aliança Brasil-Estados Unidos não era natural ou o resultado de boa vontade dos dois países, mas o resultado de um processo de negociações difíceis e continuadas. Ademais, os norte-americanos tiveram que fazer concessões, já que a aliança poderia não se firmar, devido a resistências internas brasileiras, baseadas em manifestações pró-Eixo tanto em setores sociais como nas Forças Armadas. A confiança construída entre Vargas e Roosevelt, presidente norteamericano, teria estabelecido um modelo importante para que o Brasil pudesse barganhar, o qual não foi mantido no governo de Eurico Gaspar Dutra, que experimentou a negligência de Washington, voltada para a reconstrução da Europa e para a contenção do comunismo. Segundo o autor, apesar de Dutra haver adotado inicialmente o alinhamento ideológico aos EUA, a partir dos resultados parcos dessa linha de atuação, reconheceu a marginalização do Brasil no cálculo estratégico norte-americano e reconfigurou a orientação de sua diplomacia.

A obra apresentada demonstra a importância dos estudos de Gerson Moura para o entendimento da política externa brasileira, durante e após a Segunda Guerra. A riqueza das fontes, a linguagem clara e objetiva, além da coerência analítica, reafirmam a relevância do autor para a área de conhecimento. Ao demonstrar a complexidade dos vínculos entre Brasil e Estados Unidos no período analisado, Moura contribui para desmistificar as concepções acerca de uma atitude subserviente do país sul-americano frente à potência do Norte e para afirmar que um Estado periférico desempenha papel relevante, na construção do sistema de poder liderado por Washington. A tese relançada é leitura indispensável não somente aos estudantes e aos pesquisadores de Relações Internacionais, mas àqueles que intencionam entender a formulação da política externa, no Brasil, ainda nos dias de hoje.

Palavras-chave: Brasil - Estados Unidos - Segunda Guerra Mundial 